\title{
Circulating Insulin: the Proinsulin-Like Properties of "Big" Insulin in Patients without Islet Cell Tumors
}

\author{
Barry M. Sherman, Phillip Gorden, Jesse Roth, and \\ PierRe Freychet \\ From the Diabetes Section, Clinical Endocrinology Branch, National Institute \\ of Arthritis and Metabolic Diseases, National Institutes of Health, \\ Bethesda, Maryland 20014
}

A B S T RA C T When plasma is filtered on Sephadex G-50, insulin immunoreactivity is recovered in two peaks. "Big" insulin, the higher molecular weight component, and "little" insulin, the lower molecular weight component, have elution volumes that correspond to those of proinsulin- ${ }^{128} \mathrm{I}$ and insulin- ${ }^{125} \mathrm{I}$ respectively. When plasma was extracted with acid ethanol and filtered in $1.0 \mathrm{~m}$ acetic acid, the patterns and proportions of "big" and "little" insulin were indistinguishable from those obtained by filtration of whole plasma in neutral buffer. When "big" insulin was isolated from plasma and mixed with a tracer of porcine proinsulin- ${ }^{125} \mathrm{I}$, trypsin converted the "big" insulin immunoreactivity to the gel filtration pattern of "little" insulin in the same way that it converted the proinsulin radioactivity. More than $90 \%$ of both "big" insulin and proinsulin were converted at optimal trypsin concentrations. Our present guinea pig anti-insulin serum failed to distinguish "big" from "little" but a porcine proinsulin anti-serum, under appropriate conditions of assay, reacted strongly with "big" insulin but not at all with "little." When tested on isolated fat cells, "little" insulin had the same bioactivity as porcine insulin, whereas "big" insulin had the same low activity as porcine proinsulin. These studies suggest that "big" insulin represents either single-chain proinsulin and/or a proinsulin intermediate that has similar low bioactivity.

Portions of this work were presented at the American Federation For Clinical Research Eastern Section Meeting, December 1969, and at the National Meeting, May 1970 $(1,2)$.

Dr. Freychet's permanent address is Groupe Parvis U-55 (I.N.S.E.R.M.), Hotel Dieu, 1 Place du Paris NotreDame, Paris 4, France.

Received for publication 25 May 1970 and in revised form 23 November 1970.

\section{INTRODUCTION}

Insulin is synthesized as a single-chain polypeptide, proinsulin, most of which is converted to insulin within the $\beta$-cell (3-5). When pancreatic extracts or commercial insulins are filtered on Sephadex G-50, proinsulin and other insulin-like substances are recovered in a peak that is eluted ahead of insulin. Each component of this earlier peak contains the complete insulin molecule as part of its structure, yet each has distinctive chemical, immunochemical, and biological characteristics (5).

When plasma is filtered on Sephadex G-50, a portion of the insulin immunoreactivity elutes in a region comparable to proinsulin-"big" insulin $(6,7)$. The majority of the insulin immunoreactivity is recovered in the region comparable to insulin- "little" insulin. Both components come from the pancreas and some of the physiological conditions that produce fluctuations in each of the components have been described (6-8).

In the present study we have characterized further the "big" and "little" insulins. Their low concentrations in plasma and the lack of proinsulin and proinsulin intermediates from human pancreas limited our study to a comparison of "big" and "little" insulin in human plasma with proinsulin and insulin from porcine pancreas.

\section{METHODS}

Human serum albumin (HSA) (Pentex, crystallized) was iodinated with ${ }^{125} \mathrm{I}$ (Union Carbide) at $2 \mu \mathrm{Ci} / \mu \mathrm{g}$ and freed of radioactive contaminants by batch adsorption with Dowex $1 \times 10$. Porcine insulin and porcine proinsulin ${ }^{1}$ were iodinated with ${ }^{181} \mathrm{I}$ (Union Carbide) and ${ }^{105} \mathrm{I}$ at specific activities of $200-300 \mu \mathrm{Ci} / \mu \mathrm{g}$ and freed of radioactive contaminants by adsorption to cellulose (9).

Unless otherwise noted, studies were performed at $4^{\circ} \mathrm{C}$ and the diluent was $0.05 \mathrm{~m}$ Veronal buffer, $\mathrm{pH} 8.6$, containing HSA $(2.5 \mathrm{mg} / \mathrm{ml})$ and rabbit plasma Cohn fraction

\footnotetext{
${ }^{1}$ Gifts of Dr. Ronald Chance and the Eli Lilly Company.
} 


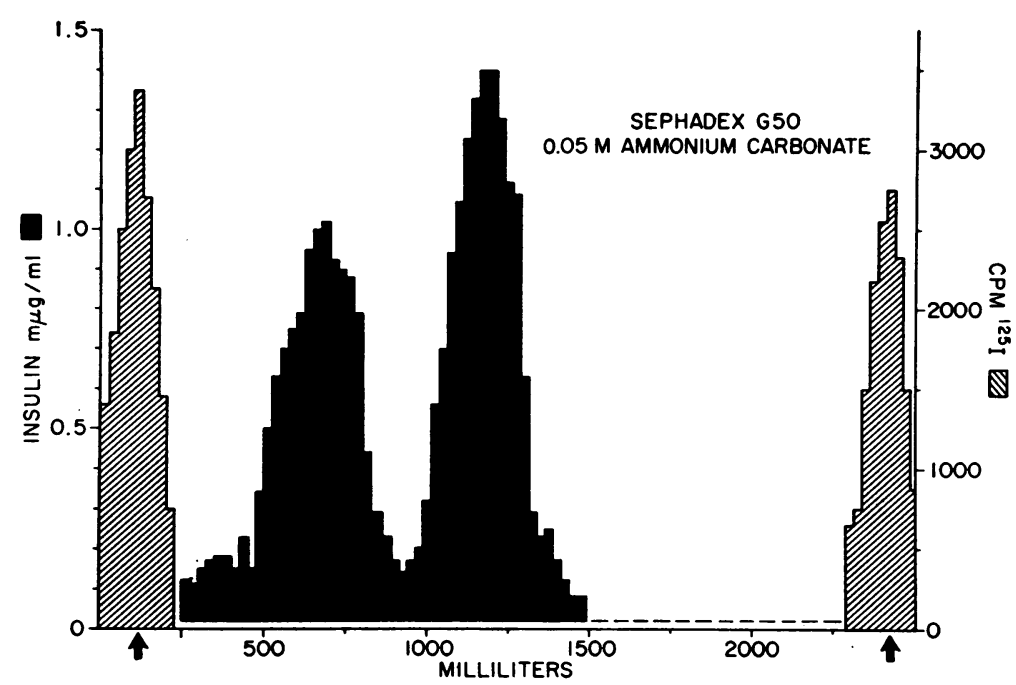

Figure 1 Preparation of "big" and "little" insulin by gel filtration. Plasma $(250 \mathrm{ml})$ was filtered on an $8 \times 100 \mathrm{~cm}$ column of Sephadex G-50 "fine." Albumin- ${ }^{125} \mathrm{I}$ and ${ }^{125} \mathrm{I}$, added to the plasma, marked the void and salt volumes which are denoted by the arrows.

II (Pentex, $0.1 \mathrm{mg} / \mathrm{ml}$ ). For analytic discrimination of "big" and "little" insulin, 1- to 2-ml samples were applied to a $1 \times 50 \mathrm{~cm}$ column of Sephadex G-50 that had been equilibrated in diluent (6). $1 \mathrm{ml}$ fractions were collected; 0.8 $\mathrm{ml}$ aliquots were assayed for insulin. To prepare large quantities of "big" and "little" insulin, $250 \mathrm{ml}$ of plasma was filtered on an $8 \times 100 \mathrm{~cm}$ column of Sephadex G-50 that had been equilibrated in $0.05 \mathrm{M}\left(\mathrm{NH}_{4}\right)_{2} \mathrm{CO}_{3}, \mathrm{pH} 9.0$ (Fig. 1, Table I). Fractions of $30 \mathrm{ml}$ each were collected; $1 \mathrm{ml}$ aliquots were lyophilized, reconstituted in diluent, and assayed for insulin. The fractions corresponding to "big" insulin and "little" insulin were pooled, lyophilized, and stored at $-20^{\circ} \mathrm{C}$ until used. The digestion with trypsin is described in the legends to the figures. For most studies

TABLE I

Characteristics of Donors of Plasma for "Big" Insulin Isolation

\begin{tabular}{|c|c|c|c|c|c|}
\hline \multirow[b]{2}{*}{ Subject } & \multirow[b]{2}{*}{ Sex } & \multirow[b]{2}{*}{ Age } & \multirow{2}{*}{$\begin{array}{c}\text { Ideal } \\
\text { body wt. }\end{array}$} & \multicolumn{2}{|c|}{$\begin{array}{l}\text { Standard GTT } \\
\text { blood glucose }\end{array}$} \\
\hline & & & & $0 \mathrm{hr}$ & $2 \mathrm{hr}$ \\
\hline & & $y r$ & $\%$ & \multicolumn{2}{|c|}{$\mathrm{mg} / 100 \mathrm{mg}$} \\
\hline F. I. E. & $\mathrm{F}$ & 20 & 100 & 84 & 105 \\
\hline S. C. H. & M & 19 & 100 & 94 & 110 \\
\hline B. E. L. & $\mathrm{F}$ & 16 & - 180 & 90 & 158 \\
\hline M. I. T. & $\mathrm{F}$ & 54 & 130 & 214 & 396 \\
\hline C. W. N. & $\mathbf{M}$ & 43 & 180 & 105 & 197 \\
\hline
\end{tabular}

Volunteers were fed a high carbohydrate diet for 3 days after which a standard $100 \mathrm{~g}$ oral tolerance test was performed; the 0 and $2 \mathrm{hr}$ values for blood glucose in this test are shown. To obtain plasma with high concentration of "big" insulin, the volunteers were fasted for $40 \mathrm{hr}$, given $100 \mathrm{~g}$ of glucose orally and $2 \mathrm{hr}$ later were subjected to plasmaphoresis. In patient M. I. T. the fast preceding the plasmaphoresis was only $12 \mathrm{hr}$. of conversion by trypsin, "big" insulin was used within a few days of its isolation.

For immunoassay, porcine insulin- ${ }^{131} \mathrm{I}$, unlabeled porcine insulin, and guinea pig anti-porcine insulin serum ${ }^{2}$ were used unless otherwise indicated. Bound and free hormone were separated by the addition of rabbit anti-guinea pig gamma globulin (6).

Biological activity was measured as the conversion of glucose- $1-{ }^{14} \mathrm{C}$ to ${ }^{14} \mathrm{CO}_{2}$ by isolated fat cells $(10,11)$. Cells were isolated from the epididymal fat of young rats by exposure to collagenase. Each incubation flask in a total volume of $2 \mathrm{ml}$ of Krebs-Ringer bicarbonate buffer contained fat cells $(15 \mathrm{mg} / \mathrm{ml})$, glucose $(0.15 \mu$ moles $/ \mathrm{ml})$, glucose-U${ }^{14} \mathrm{C}\left(2.2 \times 10^{5} \mathrm{dpm} / \mathrm{ml}\right.$, New England Nuclear $)$, and albumin (20 $\mathrm{mg} / \mathrm{ml}$, bovine Fraction V, Armour), adjusted to $\mathrm{pH}$ 7.4 under an atmosphere of $95 \% \mathrm{O}_{2}-5 \% \mathrm{CO}_{2}$. After shaking for $2 \mathrm{hr}$ at $37^{\circ} \mathrm{C}$, the $\mathrm{CO}_{2}$ was trapped in Hyamine and counted in a liquid scintillation spectrometer.

\section{RESULTS}

Gel filtration. When plasma was filtered on Sephadex G-50 in ( $\left.\mathrm{NH}_{4}\right)_{2} \mathrm{CO}_{3}$, "big" insulin was separated almost completely from "little" insulin and from the plasma proteins (Fig. 1). When the isolated "big" insulin was filtered on Sephadex G-50, the immunoreactivity was recovered in a single peak; when "big" insulin was mixed with a tracer of porcine proinsulin- ${ }^{125} \mathrm{I}$ and filtered, the peaks of immunoreactivity and radioactivity were coincident. Furthermore, when plasma was extracted by a method used for the isolation of insulin and proinsulin from pancreas (12) (acid ethanol, $\mathrm{pH}$ adjustments, isoelectric precipitation with ether) and filtered on Sephadex G-50, the location and relative

${ }^{2}$ Gift of Doctors A. Kagan and S. M. Glick. 
proportions of "big" and "little" were the same as those obtained by filtration of whole plasma.

Concersion of "big" to "little". Without trypsin, incubation at $37^{\circ} \mathrm{C}$ for 3 hr produced no change in "big." insulin (Fig. 2A), while trypsin 20-200 $\mu \mathrm{g} / \mathrm{mll}$ transformed 90\% of "big" insulin to "little" insulin (Fig. $2 \mathrm{~B}$ and $\mathrm{C}$ ). A 10-fold greater concentration of trypsin (2 $\mathrm{mg} / \mathrm{ml}$ ) caused insulin degradation (Fig. $2 \mathrm{D}$ ). In contrast another "big" insulin preparation failed to transform completely even with $2 \mathrm{mg} / \mathrm{ml}$ of trypsin (Fig. 3).

Because the concentration of trypsin required for complete conversion varied among the individual preparations of "big" insulin and because "big" insulin required 20-200 times higher concentrations of trypsin than are required for conversion of pure porcine proinsulin (5), proinsulin- ${ }^{125} \mathrm{I}$ was mixed with "big" insulin

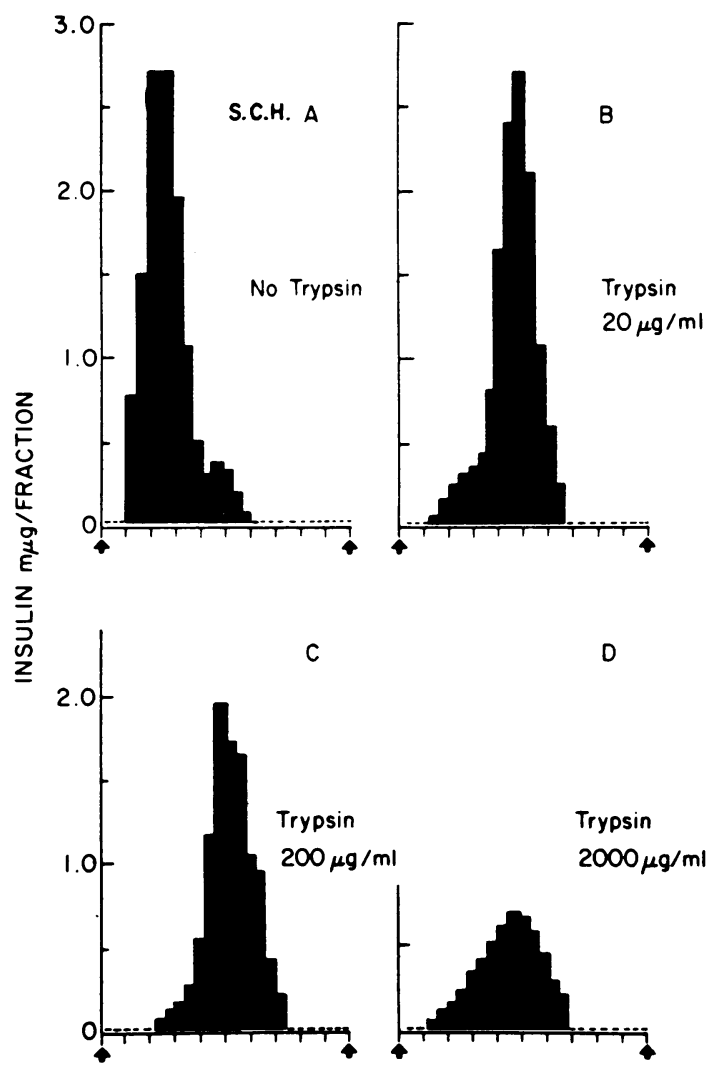

Figicke 2 Conversion of "big" to "little" insulin by trypsin. The lyophilized "big" insulin (10-20 $\mathrm{m} \mu \mathrm{g}$ ) from normal subject S. C. H. was dissolved in $1 \mathrm{ml}$ of $0.04 \mathrm{M}$ Tris buffer $\mathrm{pH} 9.4$ and mixed with TPCK (L-1-tosylamido-2-phenylethyl chloromethyl ketone) trypsin (Worthington Biochemical Corp.) at $0-200 \mu \mathrm{g} / \mathrm{ml}$. After $3 \mathrm{hr}$ at $37^{\circ} \mathrm{C}$ a 10 -fold excess of soybean trypsin inhibitor (Sigma Chemical Co.) was added and the entire reaction mixture filtered on a $1 \times 50 \mathrm{~cm}$ column of Sephadex G-50 in diluent. $1 \mathrm{ml}$ fractions were collected and assayed for insulin.

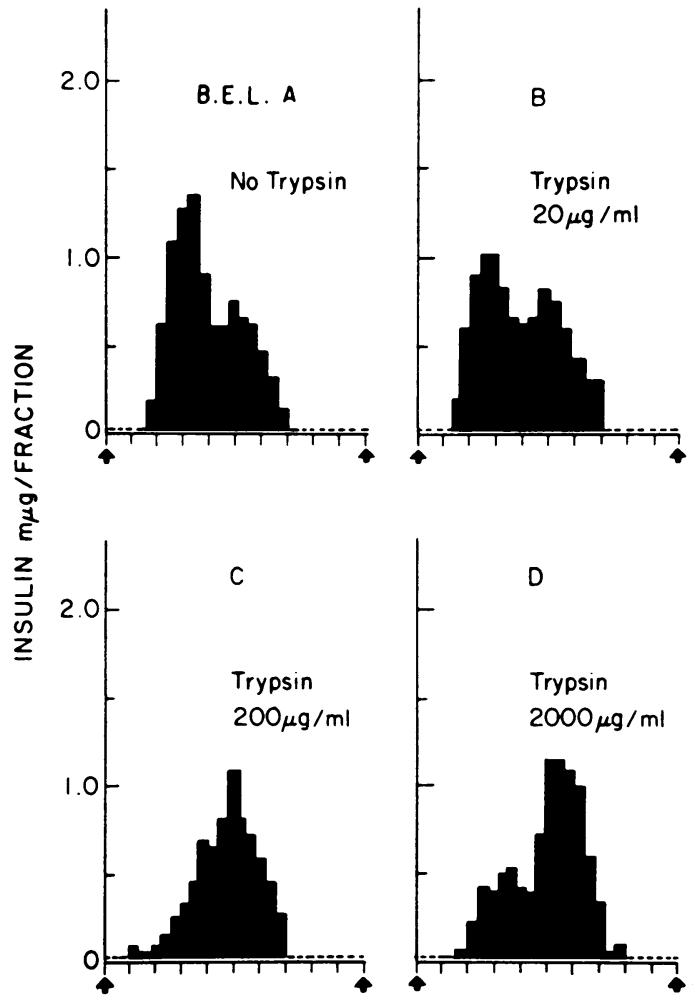

Figure 3 Conversion of "big" to "little" insulin by trypsin. Isolated "big" insulin (10-20 $\mathrm{m} \mu \mathrm{g})$ from obese subject B. E. I. was exposed to trypsin and after $3 \mathrm{hr}$ filtered on Sephadex G-50. See legend to Fig. 2.

and their trypsin sensitivities compared. With each of three "big" insulin preparations (from two normal subjects and one obese diabetic patient) at each concentration of trypsin, the degree of conversion of "big" insulin was the same as that of proinsulin ${ }^{125} \mathrm{I}$ (Figs. 4 and 5). The only difference in the conversion of "big" insulin immunoreactivity and proinsulin $-{ }^{125}$ I radioactivity was that at relatively low trypsin concentrations, a small peak of immunoreactivity appeared which was intermediate in position (Fig. 4: S.C.H. with $0.5 \mu \mathrm{g}$ trypsin, F.I.E. with $5.0 \mu \mathrm{g}$ trypsin) and which disappeared at higher concentrations of enzyme. At optimal trypsin concentrations more than $90 \%$ of the "big" insulin and proinsulin- ${ }^{125} \mathrm{I}$ converted (Figs. 4 and 5). Because we suspected that some contamination with plasma proteins in the "big" insulin preparations might be the cause of the relative resistance to trypsin, "big" insulin was purified further by a second filtration on Sephadex G-50. In this case, less than $1 \mu \mathrm{g} / \mathrm{ml}$ of trypsin converted more than $80 c_{c}^{\prime}$ of the "big" insulin (Table II), which is comparable to results obtained with pure proinsulin (5).

At all enzyme concentrations, recoveries of total radioactivity and of immunoreactivity were $80-120 \%$; 
reductions in "big" insulin immunoreactivity were accounted for fully by increases in "little" insulin. This suggests that "big" insulin, on a molar basis, reacted with this antiserum about as well as "little" insulin.

Immunologic characterization. With the guinea pig anti-porcine insulin serum that was used in these studies, porcine proinsulin on a molar basis was $25 \%$ less reactive and human insulin was $40 \%$ less reactive than porcine insulin (Figs. 6 and 7). However, the curves of porcine insulin, human insulin, and porcine proin- sulin, tested over a 100 -fold range of concentrations, had the same shape and could be superimposed (Figs. 6 and 7). Presumably the quantitative immunologic distinction made by this antiserum was due to a constant difference in affinity of each insulin for the entire antibody population; without an absolute measurement of concentration, based on their weights, we would have found no distinction between porcine insulin, human insulin, and porcine proinsulin. "Little" insulin was tested over a 20 - to 30 -fold range of dilution and "big"



FIgURE 4 Trypsinization of a mixture of "big" insulin and proinsulin- ${ }^{125} \mathrm{I}$. "Big" insulin (10$20 \mathrm{~m} \mu \mathrm{g})$ was mixed with proinsulin- ${ }^{125} \mathrm{I}(5000 \mathrm{cpm}, 0.075 \mathrm{~m} \mu \mathrm{g})$ and incubated with trypsin. After $3 \mathrm{hr}$ trypsin inhibitor was added and the mixture filtered on Sephadex. (See legend, Fig. 2). Radioactivity and immunoreactivity were determined on each fraction and plotted as a function of the column volume. Recovery of immunoreactivity and radioactivity ranged from 80 to $120 \%$. 


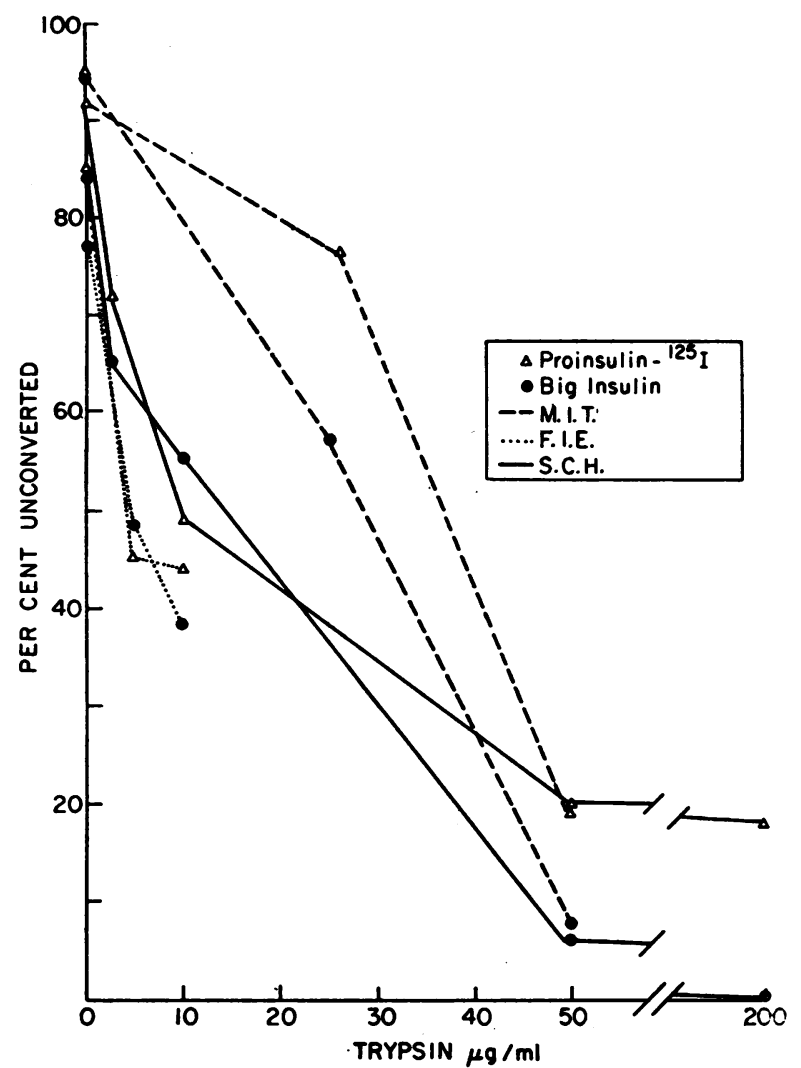

FIGURE 5 Comparison of "big" insulin and proinsulin- ${ }^{125} \mathrm{I}$ sensitivity to trypsin. From the experiments in Fig. 4 the percentages of unconverted "big" insulin and proinsulin- ${ }^{25} \mathrm{I}$ are plotted as a function of the trypsin concentration for each of the three plasmas studied.

insulin was tested over a 30 - to 40 -fold range; both were indistinguishable from porcine insulin (Figs. 8 and 9). This experiment did not exclude a substantial quantitative difference between "big" and "little" insulin and porcine insulin that was undetected because we lacked a weighed quantity of purified plasma "big" or "little" insulin.

"Big" and "little" insulin were readily distinguished by the use of labeled porcine proinsulin with a guinea pig anti-porcine proinsulin serum ${ }^{3}$ (Fig. 10) that had been preincubated with an excess of porcine insulin to block the insulin-specific antibody sites (13). Under these conditions "big" insulin and proinsulin competed fairly strongly whereas "little" insulin and porcine insulin failed to bind. Note, however, that in this system porcine proinsulin was bound more strongly than was human "big" insulin. This difference presumably reflects the $50 \%$ difference in amino acid composition

${ }^{3}$ Gift of Dr. M. Root.
TABLE II

Effectof Repeated Filtration of "Big" Insulin on Its Sensitivity to Trypsin

\begin{tabular}{|c|c|c|c|c|}
\hline \multirow[b]{2}{*}{ Trypsin } & \multicolumn{3}{|c|}{$\begin{array}{l}\text { Insulin recovered after trypsin } \\
\text { and final filtration }\end{array}$} & \multirow[b]{2}{*}{ Conversion } \\
\hline & "Big" & "Little" & $\begin{array}{c}\text { "Big" } \\
+ \\
\text { "Little" }\end{array}$ & \\
\hline$\mu g / m l$ & & $m \mu g$ & & $\%$ \\
\hline 0 & 3.0 & 0.4 & 3.40 & 9 \\
\hline 0.1 & 0.90 & 2.44 & 3.34 & 73 \\
\hline 0.3 & 0.45 & 3.20 & 3.65 & 88 \\
\hline 0.5 & 0.53 & 2.95 & 3.48 & 85 \\
\hline
\end{tabular}

Plasma was filtered over Sephadex G-50. The effluent fractions corresponding to "big" insulin were pooled, concentrated, and refiltered on Sephadex G-50, and the "big" insulin was again pooled and concentrated. Aliquots were exposed to trypsin for $3 \mathrm{hr}$ at $37^{\circ} \mathrm{C}$, the reaction mixture was filtered on a $1 \times 50 \mathrm{~cm}$ column of Sephadex G-50, and each fraction assayed for insulin. See legend to Fig. 2.

between porcine and human connecting peptides (14 16).

Biological activity. In a series of experiments, with insulin at $25 \mu \mathrm{U} / \mathrm{m} \mu \mathrm{g}$, we found that our purified porcine proinsulin had a relative biological activity of $1.72 \pm 0.10 \mu \mathrm{U} / \mathrm{m} \mu \mathrm{g}$, corresponding on a molar basis to activity $11 \%$ that of the insulin. When isolated plasma components from an obese subject (C.W.N.) were bioassayed, the "little" insulin was indistinguishable from porcine insulin and the "big" insulin was indistinguishable from porcine proinsulin (Fig. 11). In ^other experiments, by use of another porcine proinsulin which bioassayed at $0.35-0.50 \mu \mathrm{U} / \mathrm{m} \mu \mathrm{g}$, the "little" insulin isolated from a normal volunteer (S.C.H.) had 19-22 $\mu \mathrm{U}$ of biological activity per m $\mu \mathrm{g}$ of immunoreactivity and "big" insulin from the same sample had $0.25-0.40 \mu \mathrm{U} /$ $\mathrm{m} \mu \mathrm{g}$. Note that if a correction had been applied for the lower immunoreactivity of the human materials, the specific biological activity of "big" and "little" insulin would have been moderately lower.

\section{DISCUSSION}

The characterization of "big" insulin was limited by the minute amounts of materials, their impure state, and the unavailability of purified human proinsulin. Our study was therefore largely limited to a comparison of "big" and "little" insulin from human plasma to purified insulin and proinsulin from porcine pancreas.

From its position on gel filtration, its sensitivity to trypsin, and its strong reactivity with insulin- and proinsulin-specific antisera, we can conclude that the "big" 


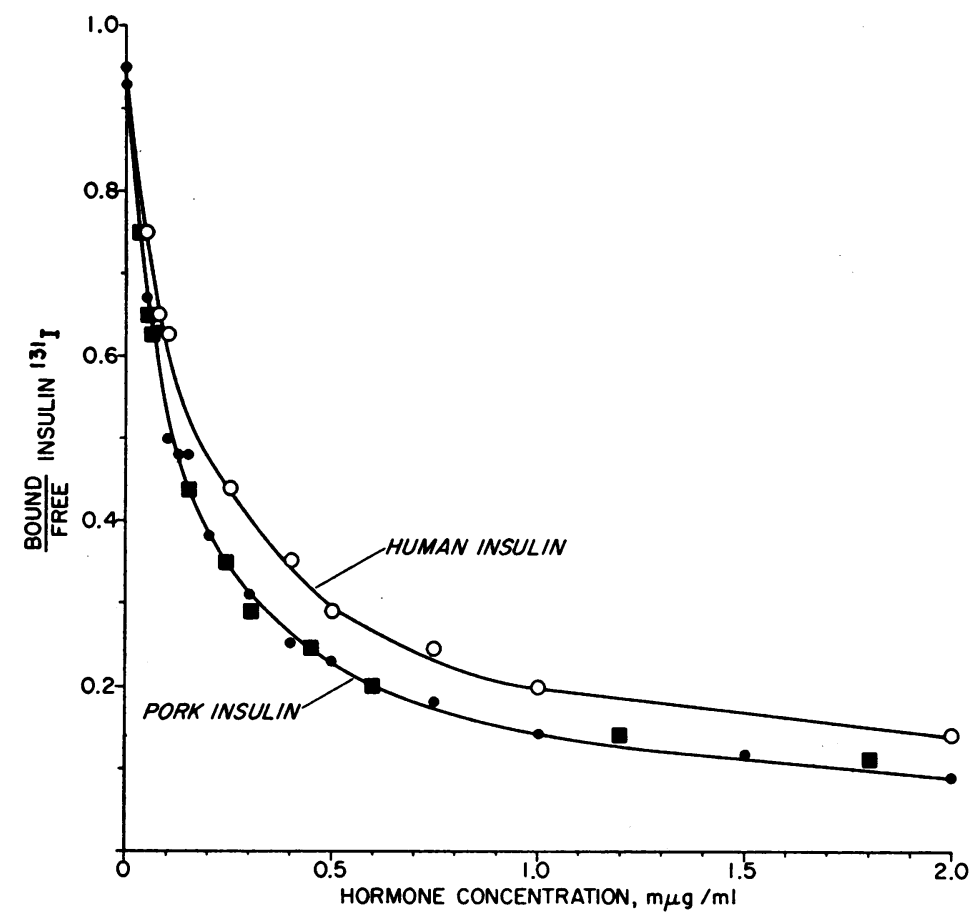

FIGURE 6 Immunologic reactivity of porcine insulin and human pancreatic insulin. Bound/free $(B / F)$ of porcine insulin- ${ }^{131} \mathrm{I}$ is plotted as a function of the concentrations of porcine insulin (-๑) and of human insulin $(\mathrm{O}-\mathrm{O})$. To compare the shapes of the curves, the scale of human insulin concentration was reduced (not shown) to give the best fit on the porcine insulin curve and the points of human insulin (a) were replotted accordingly.

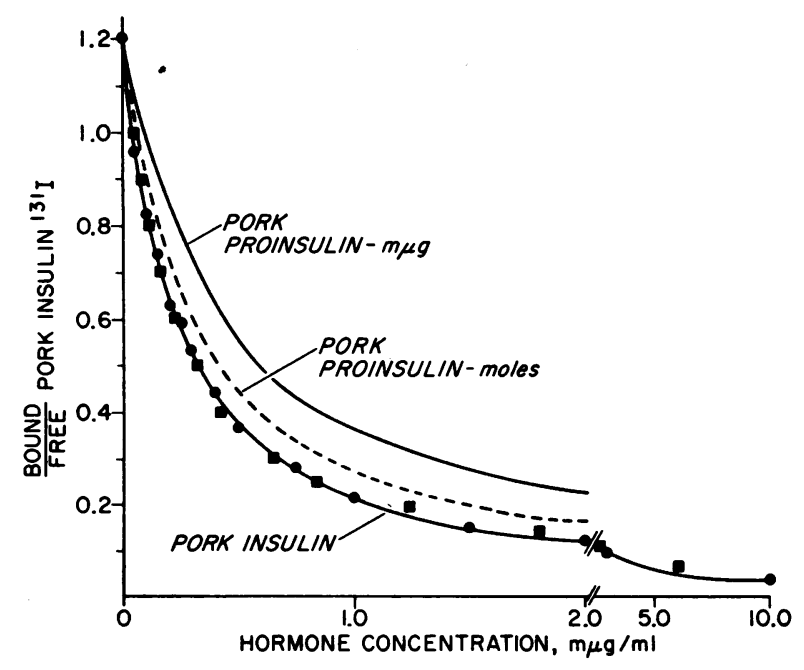

FIGURE 7 Immunologic reactivity of porcine insulin and porcine proinsulin. Bound/free of porcine insulin- ${ }^{181} I$ was plotted as a function of the concentration of unlabeled porcine insulin (-@) and proinsulin (-). The proinsulin curve was adjusted to account for its $\frac{1}{3}$ greater molecular weight $(----)$. The scale of porcine proinsulin was reduced to give the best fit on the porcine insulin curve and the points replotted accordingly ( $\mathbf{a})$. insulin component contains both insulin and a major portion of the connecting segment and thus represents either single-chain proinsulin or one of the two-chain proinsulin intermediates that still retains most of the connecting segment. Similar conclusions were reached by Melani, Rubenstein, and Steiner (17) and by Lazarus, Tanese, Gutman, and Recant (18), from their studies, though they lacked experiments to distinguish proinsulin from one or more of its intermediates. Since we found that the biological activity of "big" insulin was so low, relative to its immunological reactivity, we suggest that the "big" insulin is either one-chain proinsulin or a two-chain proinsulin intermediate of very low biological activity, possibly similar to the porcine proinsulin intermediate in which the 54-55 bond in the connecting segment is split (split proinsulin). We attempted to distinguish further between the one-chain and two-chain forms by subjecting "big" insulin to reduction and reoxidation and to acrylamide-gel electrophoresis (5), but we were unsuccessful in adapting

' Chance, R. E. Personal communication. 


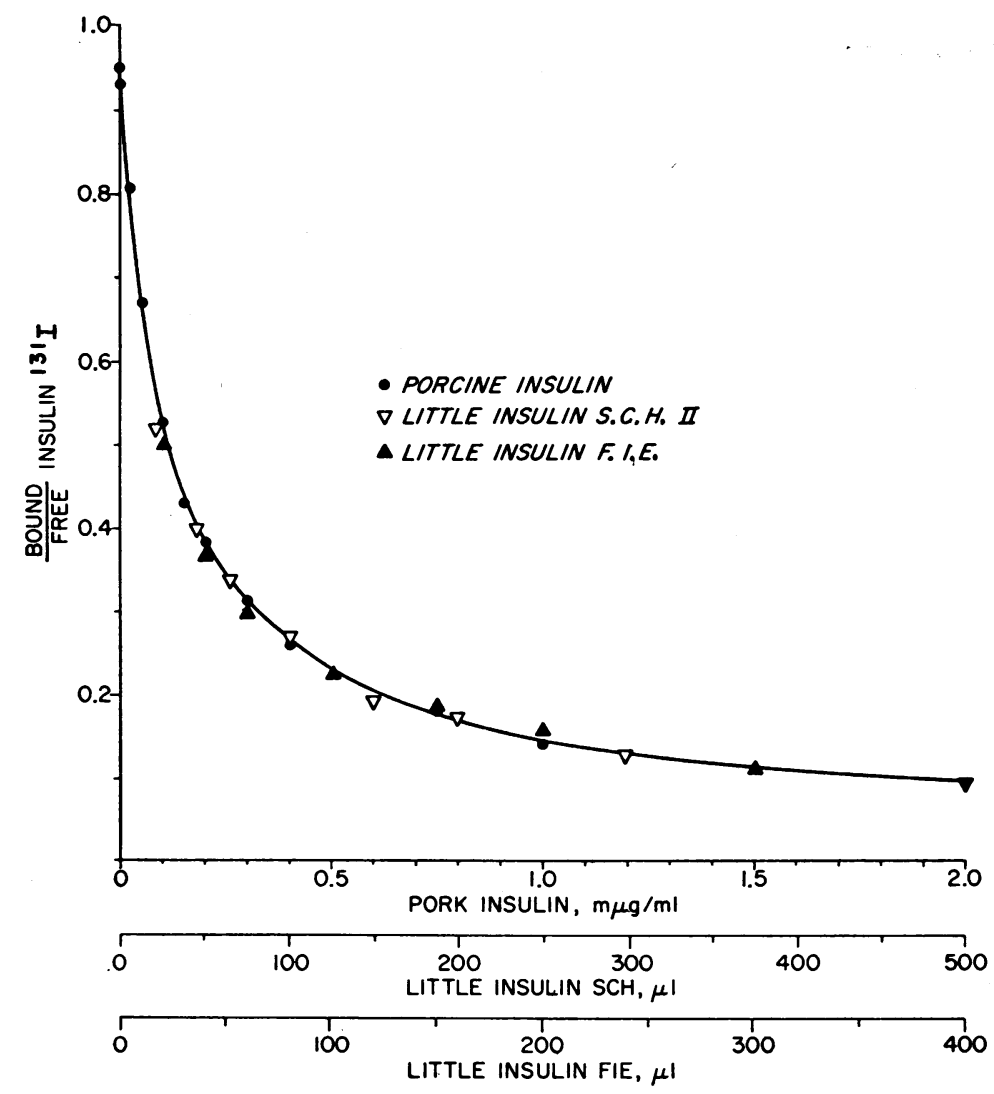

FIGURE 8 Immunologic reactivity of "little" insulin and porcine insulin. Multiple aliquots of isolated "little" insulin were assayed. The bound/ free of porcine insulin- ${ }^{-181} \mathrm{I}$ is plotted as a function of the concentration of unlabeled porcine insulin and of the volumes of the "little" insulin concentrates.

these techniques to nanogram quantities of material. In some of our samples at relatively low trypsin concentrations, some of the "big" insulin but not the proinsulin${ }^{181}$ I was found in a region between that of proinsulin and insulin. Proinsulin with a 54-55 split, when treated with trypsin, would yield such an intermediate (desnonapeptide proinsulin), whereas single-chain proinsulin would not yield a component of intermediate mobility. It should be noted that porcine proinsulin and split proinsulin have biological activities in vivo and in vitro, immunological reactivities, and gel filtration patterns that are about the same. Human proinsulin, though it has a $50 \%$ difference in the composition of its connecting segment, has a leucyl-alanyl bond in a position similar to that in the porcine connecting segment. Finally it is still unclear whether split proinsulin occurs in vivo or whether its appearance represents some proteolytic event during collection and processing.

Melani, Rubenstein, and Steiner (17) found that the products of tryptic conversion of circulating proinsulin had enhanced immunological reactivity, presumably be- cause their anti-porcine insulin serum was more reactive with human insulin than with human proinsulin. We failed to find any difference in immunological reactivity after conversion because our antiserum did not distinguish "big" from "little." A previous antiserum that we had used, the supply of which is now exhausted, did distinguish "big" from "little" (6) and presumably would have detected an increase in immunoreactivity after trypsin treatment of "big."

The "big" insulins obtained from the normal, obese, and diabetic subjects were indistinguishable on gel filtration, and as to sensitivity to trypsin and immunological reactivity. Thus far we have no evidence for the existence of an abnormal form of proinsulin in these disorders. Our studies were limited to "big" insulin obtained $2 \mathrm{hr}$ after oral glucose administration from patients without islet cell tumors. Further studies with "big" insulin obtained under other physiological circumstances and in other disordered states such as tumors are necessary before we can generalize on the identity of "big" insulin. 

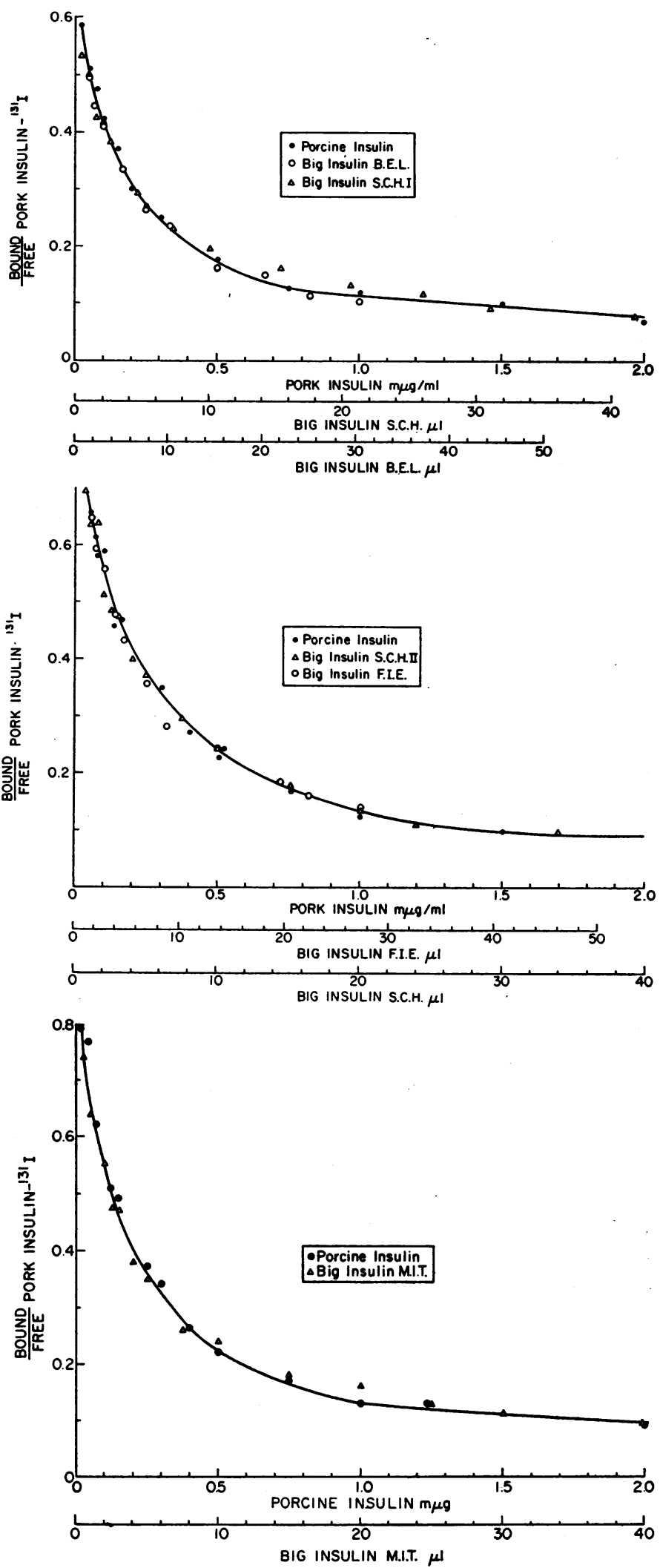

FIGURE 9 Immunologic reactivity of "big" insulin and porcine insulin. Bound/free of porcine insulin- ${ }^{12} I$ is plotted as a function of the concentrations of unlabeled porcine insulin and of the volume of the "big" insulin concentrates. 


\section{ACKNOWLEDGMENTS}

We are grateful to C. M. Hendricks for superior technical assistance and to Dr. J. Gliemann for some of the studies in isolated fat cells on plasma components from patient S.C.H.

Dr. Freychet is the recipient of a U. S. Public Health Service International Postdoctoral Research Fellowship (1 F05TW01512-01).

\section{REFERENCES}

1. Sherman, B., P. Gorden, and J. Roth. 1969. Characterization of "big" insulin. Clin. Res. 17: 613. (Abstr.)

2. Sherman, B., P. Gorden, J. Roth, and J. Gliemann. 1970. "Big" insulin: circulating proinsulin. Clin. Res. 18: 372. (Abstr.)

3. Steiner, D. F., and P. E. Oyer. 1967. The biosynthesis of insulin and a probably precursor of insulin by a human islet cell adenoma. Proc. Nat. Acad. Sci. U.S.A. $57: 473$.

4. Steiner, D. F., D. Cunningham, L. Spigelman, and B. Aten. 1967. Insulin biosynthesis: evidence for a precursor. Science (Washington). 157: 697.

5. Steiner, D. F., J. T. Clark, C. E. Nolan, A. H. Rubenstein, E. Margoliash, B. Aten, and P. E. Oyer. 1969. Proinsulin and the biosynthesis of insulin. Recent Progr. Hormone Res. 25: 207.

6. Roth, J., P. Gorden, and I. Pastan. 1968. "Big" insulin: a new component of plasma insulin detected by immunoassay. Proc. Nat. Acad. Sci. U.S.A. 61: 138.

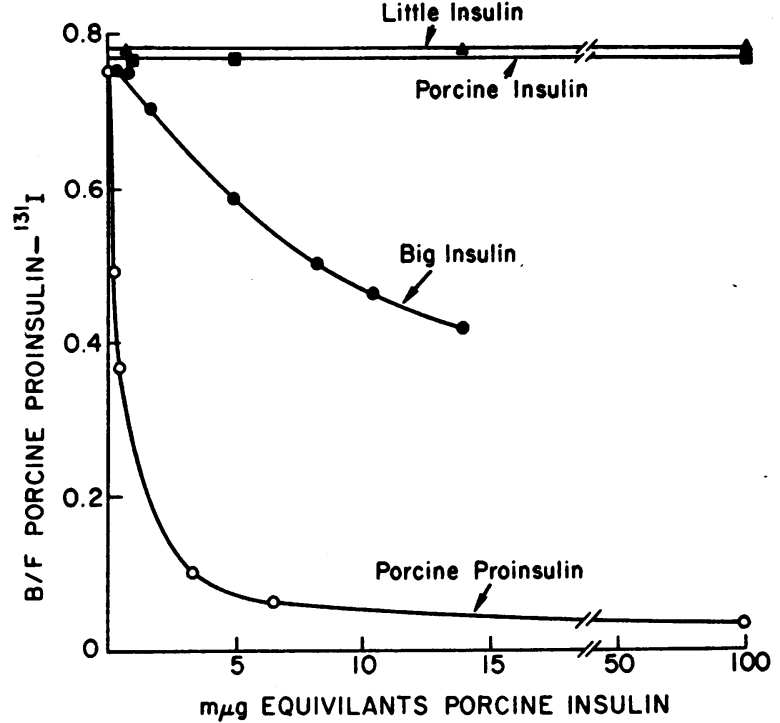

FIGURE 10 Immunologic reactivity with anti-proinsulin serum. Guinea pig anti-proinsulin serum was preincubated with an excess of porcine insulin. Bound/free of porcine proinsulin- ${ }^{131} \mathrm{I}$ was plotted as a function of the concentrations of porcine insulin. The scale of porcine proinsulin was appropriately reduced to account for its higher molecular weight.

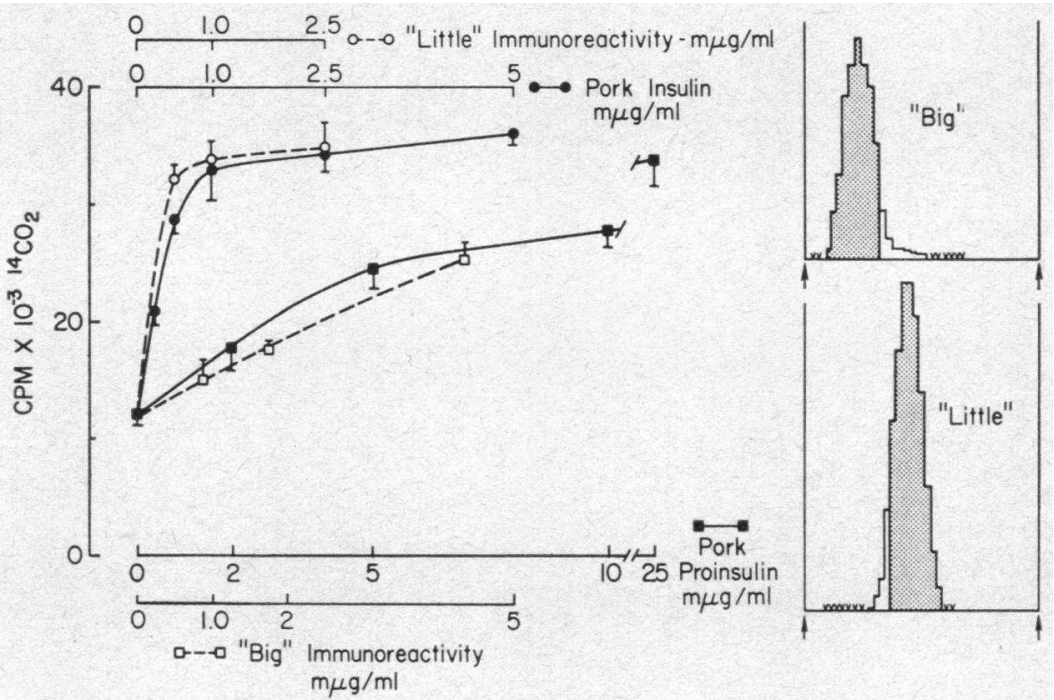

FIgURE 11 Biological activity in isolated fat cells. Plasma from an obese subject (C. W. N.) was filtered on Sephadex and the fractions corresponding to "big" and to "little" were pooled and lyophilized. Each pool was filtered again $(1.5 \times 90 \mathrm{~cm}$ column $)$ and the effluent fractions immunoassayed for insulin (see insets at the right). The fractions denoted by the shaded area were pooled and lyophilized. For assay they were dissolved in Krebs-Ringer phosphate buffer, $\mathrm{pH} \mathrm{7.4,} \mathrm{which} \mathrm{contained} \mathrm{albumin} 2.5 \mathrm{mg} / \mathrm{ml}$ to yield "big" and "little" with concentrations of immunoreactivity of 175 and $100 \mathrm{~m} \mu \mathrm{g} / \mathrm{ml}$, respectively, assayed against the porcine insulin standard. In the figure at the left, counts per minute of ${ }^{14} \mathrm{CO}_{2}$ produced is plotted as a function of the concentration of hormone. Each point is the mean ISEM of three determinations in a single assay. The proinsulin scale has been adjusted so that insulin and proinsulin correspond on a molar basis. 
7. Gorden, P., and J. Roth. 1969. Circulating insulins. Arch. Intern. Med. 123: 237.

8. Gorden, P., and J. Roth. 1969. Plasma insulin: fluctuations in the "big" insulin component in man after glucose and other stimuli. J. Clin. Invest. 48: 2225.

9. Yalow, R. S., and S. A. Berson. 1960. Immunoassay of endogenous plasma insulin in man. J. Clin. Invest. 39: 1157 .

10 Gliemann, J. 1966. Assay of insulin-like activity by the isolated fat cell method. Diabetologia. 3: 382.

11. Rodbell, M. 1964. Metabolism of isolated fat cells. Effects of hormones on glucose metabolism and lipolysis. J. Biol. Chem. 239: 375 .

12. Davoren, P. R. 1962. The isolation of insulin from a single cat pancreas. Biochim. Biophys. Acta. 63: 150

13. Yip, C. C., and J. Logothetopoulos. 1969. A specific anti-proinsulin serum and the presence of proinsulin in calf serum Proc. Nat. Acad. Sci. U.S.A. 62: 415.

14. Chance, R. E., R. M. Ellis, and W. W. Bromer. 1968. Porcine proinsulin: characterization and amino acid sequence. Science (Washington). 161: 165.

15. Oyer, P. E., S. Cho, and D. F. Steiner. 1970. Isolation and structure of human proinsulin C-peptide. Fed. Proc. 29: 533.

16. Nolan, C., E. Margoliash, and D. F. Steiner. 1968. Bovine proinsulin. Fed. Proc. 28: 343. (Abstr.)

17. Melani, F., A. H. Rubenstein, and D. F. Steiner. 1970. Human serum proinsulin. J. Clin. Invest 49: 497.

18. Lazarus, N. R., T. Tanese, R. Gutman, and L. Recant. 1970. Synthesis and release of proinsulin and insulin by human insulinoma tissue. J. Clin. Endocrinol. 30: 273. 